Citation: Pidkuimmukha, L., \& Kiss, N. (2020). Battle of narratives: Political memes during the 2019 Ukrainian presidential election. Cognitive Studies / Études cognitives, 2020(20), Article 2246. https://doi.org/10.11649/ cs. 2246

\section{LIUDMYLA PIDKUĬMUKHA}

Ukrainian Language Department, Faculty of Humanities, National University of KyivMohyla Academy, Ukraine

https://orcid.org/0000-0003-2017-1213

1.pidkuimukha@ukma.edu.ua

\section{NADIYA KISS}

Institute for Slavic Studies, Justus Liebig University of Giessen, Germany https://orcid.org/0000-0002-2077-7605 nadiya.kiss@slavistik.uni-giessen.de

\title{
BATTLE OF NARRATIVES: POLITICAL MEMES DURING THE 2019 UKRAINIAN PRESIDENTIAL ELECTION
}

\begin{abstract}
The article highlights the peculiarities of political internet memes as information units that shape public opinion. The article also examines the role of memes in society. The research material includes creolized memes (including both verbal and visual elements) about the Ukrainian politicians Petro Poroshenko and Volodymyr Zelenskyi. These memes were created in 2019 during the Ukrainian presidential election. The article firstly focuses on the verbal aspects of the memes and their semantic and functional features. In addition, the peculiarities of opponent image construction are analysed. The article then examines the influence of Ukrainian politicians on the conduct of the "meme war". The article also sheds light on the role which memes play in the polarization of society.
\end{abstract}

Keywords: political meme; creolized meme; polarization of society; elections; image of opponent; politics in Ukraine

\section{Introduction}

A peculiarity of political internet memes frequently lies in the fact that they not only reflect ideas, but also demonstrate a certain attitude towards a political event, political power in general, or a specific political leader. Memes have served to activate young voters, a section of the electorate who have developed an interest in the political process through social media. It is not surprising that researchers have noted that "in the information era, the one who owns their own meme, has most power" (Levinson, 2007, p. 201). Political candidates have tried to create content specifically for Twitter, Instagram and Facebook, as well as to develop the networks of 'bots' in order to widen the reach of messages. During the 2019 presidential campaign in Ukraine, discrediting an opponent became a key feature of internet memes, which was expressed through evaluative judgements.

This article seeks to consider the broader popularization of the 2019 presidential election in Ukraine through memes supporting both the Poroshenko and Zelenskyi campaigns. Although memes can take multiple different formats, such as images, videos, GIFs, and hyperlinks, the 
article will focus on internet memes consisting of a verbal part (a text) and a paralinguistic part (an image).

Original photos from newsfeeds are used as the basis of the memes. Either direct speech attributed to the main character of the photo or a general caption is added to the image, the photo and text merging into one. The most popular sources of memes and doctored photos on the internet in Ukraine are a website called Durdom [lit. Loony Bin], as well as certain pages and groups on social media websites, such as Chotkii Patsa [lit. Robust Lad], Baba i Kit [lit. Granny and a Cat], Tserkva Svidkiv Pokrashchennia [lit. the Church of the Improvement Witnesses], Ministerstvo Emihratsii [lit. Ministry of Emigration], and Telebachennia Toronto [lit. Toronto TV]. The aforementioned public accounts were the source of the materials analysed in this study.

This paper applies the methodological tools of critical discourse studies. The discursive approach sheds light on how people construct meaning appropriate to cultural contexts and retrieve power from mainstream media (Huntington, 2013). The main tasks of this study are: 1) to reveal the discursive and lexical patterns of constructing the image of a political opponent in internet memes; 2) to show how humour and sarcasm were used by campaign staff, supporters and opponents in forming the images of the candidates; 3 ) to analyse the polarisation of Ukrainian society through the prism of political memes; 4) to reveal the sources of meme usage and modifications; and 5) to describe the main metaphoric models that form the basis of meme creation.

\section{Political internet memes - definitions and state-of-the-art in research methodology}

Internet memes have become an important part of everyday life. Moreover, they are a means of political expression all over the globe, especially for young people. They influence political choices and can be the cause of victory or defeat in election campaigns. Researchers of political discourses have noted the 'memeification of politics' (Dean, 2019, p. 1), write about 'Politics 2.0', 'memecracy', 'memecrat' (Piñeiro-Otero \& Martínez-Rolán, 2016), 'hacktivism' (Metahaven, 2013), and conduct research into 'mimetic politics', 'digitised politics', 'digital sociality', 'netizens' (Burroughs, 2013), and 'selfie citizenship' (Kunstmann, 2017). Therefore, it can be observed that even the language and terminology of the social sciences reflect the significance of the impact which digital technologies have had on contemporary societies. There are several motifs of the mass creation and spread of memes, among them: self-expression, the strengthening of social identity, and entertainment (for detail see Leiser, 2019).

The term "meme" was coined and introduced by the evolutionary biologist Richard Dawkins in 1976. Since the late 1970s, the term has provoked discussions in different branches of science and the humanities. However, in this paper later definitions are adhered to. For instance, Reime defines a meme as "a picture or figure functioning as a template or situational background, to which a specific and related, written content is added" (Reime, 2014, p. 2). Therefore, Reime stresses the formal characteristics of memes, thus distinguishing them from other genres, such as jokes, posters, etc. Another definition describes memes as "contagious patterns of 'cultural information' that get passed from mind to mind and directly generate and shape the mindsets and significant forms of behaviour and actions of a social group" (Knobel \& Lankshear, 2007, p. 199). In this definition, the influence of memes on modern societies is placed front and centre. The scholars also propose a scheme for the discursive analysis of online memes. Within this scheme, several research clusters are significant: 1) the referential or ideational system, with a focus on meaning; 2 ) the contextual or interpersonal system, with a focus on social relations; 3 ) the ideological or worldview system, with a focus on values and beliefs (Knobel \& Lankshear, 2007, p. 207).

In addition, Davison underlines the humorous nature of memes, describing them as "a piece of culture, typically a joke, which gains influence through online transmission" (Davison, 2012, p. 122). He also proposes a three-component model of memes, which includes manifestation, behaviour and ideal (Davison, 2012, p. 123). For the present study, two components play important 
roles: manifestation and ideal. Therefore, this paper analyses what ideas form the background for political memes in Ukraine and what manifestations (images combined with textual messages) they take. The issue of behaviour (how and by whom memes are created and spread, and on what audiences they have a larger or smaller influence) is, naturally, of great interest, but lies beyond the scope of the present study.

Huntington identifies three approaches towards meme research: semiotic, discursive and visual rhetoric (Huntington, 2013). Following these approaches, researchers are driven by different motivations - 1) the semiotic approach is interested in stylistic conventions, relationships between text and visual elements, and the significance which these factors have for meaning; 2) the discursive approach sheds light on how people construct meaning appropriate to cultural contexts and retrieve power from mainstream media; 3 ) the visual rhetoric approach emphasizes meaning-making via rhetorical elements and investigates the influence on viewers (Huntington, 2013). In practice, all these approaches are often combined. Furthermore, research of memes increases understanding of modern-day social realities by mapping "political discourses far beyond the scope of mass media and organised communities" (Seiffert-Brockmann et al., 2017, p. 15).

Both quantitative and qualitative methods are broadly applied to study memes. For instance, quantitative methods were used to analyse Twitter discourse concerning Spanish politics (PiñeiroOtero \& Martínez-Rolán, 2016). Combining content analysis of memes (meaning and formal features) with an examination of the statistical data around certain hashtags on Twitter, such as timing and interactions of followers, provides a holistic picture of the national debate in Spain (Piñeiro-Otero \& Martínez-Rolán, 2016). On the other hand, semiotic analysis of memes together with short interviews about social media use were applied to study the role of memes in political engagement amongst young people in Singapore (Sreekumar \& Vadrevu, 2013). Calimbo also provides qualitative research on political memes in the Phillipines, employing humour analysis (Calimbo, 2016). Moreover, popular Polish internet memes, including political memes, have been analysed from the perspective of cognitive linguistics (Ostanina-Olszewska \& MajdzińskaKoczorowicz, 2019). In this paper, a qualitative method has been applied, referring to the most popular memes in Ukrainian politics and analysing their meanings and the contexts in which they were created.

Several scholars have focused on the analysis of memes in Barak Obama's successful presidential campaigns in the United States (in 2008 and 2012). Researchers have claimed that these campaigns were the beginning of the huge influence of digitalisation on political life: "... the increasing pervasiveness of mimetic communication melded with social networking has once again impacted the political landscape" (Burroughs, 2013, p. 258). Analysing the "hope" meme, broadly used in Obama's election campaign, researchers applied thematic analysis, proposing four thematic clusters: organized discourse, alternative discourse, popular culture and individual culture (Seiffert-Brockmann et al., 2017, p. 11). Therefore, as the researchers conclude, "memes emerge and replicate in thematic patterns and they can be ordered along the lines of discursive types" (Seiffert-Brockmann et al., 2017, p. 15). The present study also employs thematic principles in meme classification and analysis.

It is important to note that the study of memes requires an interdisciplinary approach. Purely linguistic analysis will not succeed, since a meme is only partly of a linguistic nature: "Memes are not phenomena of language; they are phenomena with language. From words that simply 'annotate' a meme, conveying its minimally required meaning in a given context, to words that become an integral part of the meme's functioning" (Metahaven, 2013, p. 4). Researchers of memes should bear in mind the historical, socio-political and cultural contexts of meme production and spread. Reime underlines the interplay between humour and serious political issues that often appear in memes (Reime, 2014, p. 4). In addition, Chen describes memes as an "extremely contagious and often very humorous part of internet culture" (Chen, 2012, p. 7). As he notes, memes "seem to straddle very fine lines between questionable innovation and ironic kitsch as well as biting wit and profuse vulgarity" (Chen, 2012, p. 8). Moreover, playfulness and absurdism are defined as key features of successful memes (Knobel \& Lankshear, 2007, p. 217). 
In turn, investigating the humorous component of memes not only involves a knowledge of the linguistic nuances of a certain language, but also implies a deep understanding of sociocultural codes of humour, previous political jokes and anecdotes, and the rules of humour usage in political culture in general. Definitely, humour in memes has specific purposes; as Calimbo points out, it serves "to challenge dominant ideologies" (Calimbo, 2016, p. 4), and "is basically aggressive or subversive as it ridicules and satirizes representatives of power, the political elite" (Calimbo, 2016, p. 17). Therefore, qualitative research also requires knowledge of the background of all political actors involved in meme production, and the tensions and conflicts between them.

\section{The study of memes in Ukrainian academic literature}

In Ukraine the question of memes and their functioning has been studied by: Danylenko and Skalozub, who have researched the theory of memes as a factor in the formation of public opinion; Komar, who has analysed them in the context of the emergence approach; Sokolova, who has studied memes as a means of communication in the medium of the internet (Sokolova, 2012); and Zinchenko, who has analysed memes from the standpoint of psychology.

According to Pocheptsov, interest in memes is caused by "a search for tools to carry out ideological warfare not in the theoretical realm, but directly in the collective consciousness" (Pocheptsov, 2017). Pocheptsov believes that "to do this one ought to reach in their analysis the constituents of these units in order to comprehend their strengths and weaknesses" (Pocheptsov, 2017). In this way, the hybrid war in the Donbas region prompted scientists to study memes as a means of information resistance. Isakova stresses that a meme - as a collective unconscious mind at the moment of obtaining a verbal or any other sign form - has become one of the most widely-spread expressions of the language of animosity in the Ukrainian news media (Isakova, 2016, p. 94).

The meme war in Ukraine is waged primarily on social networking sites as a struggle in the field of narratives and ideas, "it is, firstly, a fight of two systems of values (civilization ideas): a Euro-Asian (imperial) one, promoted by the Russian Federation, and a Western European one (liberal, democratic) which has been supported by the Ukrainian people" (Marutian, 2017).

Presently, Ukrainian researchers are focusing ever more frequently on political memes, which exist in various language segments of the internet. Neklesova, for one, has analyzed the cases of the emergence and functioning of the meme of the "Bloody Pastor" [Kryvavyi Pastor $]^{1}$ (Neklesova, 2016). Denysiuk has studied the meme "a granny with a cat"2 [baba z kotom] (Denysiuk, 2016).

The appearance of these sorts of memes is inevitable, as more and more sections of the population are becoming internet users. Thus, memes give rise to a constant, unstoppable birth of new forms of media-literacy and provoke discussions on the subject of politics in everyday life (Tryon, 2016).

According to researchers, the active sharing of posts on social networking sites is connected to the socio-psychological desire to add one's voice to the general information stream in order to share experiences with others, and by doing so to bolster one's self-esteem. Personal pages on the internet prove that their authors frequently demonstrate thoughts, stereotypes and tendencies which they otherwise do not make public, or even consciously hide, elsewhere (Kxiva \& Vesik, 2009, p. 100).

Dziubina, examining internet memes on Facebook and Twitter, has drawn a distinction between creolized memes and textual memes. This analysis has confirmed the importance of the internet

\footnotetext{
1"Kryvavyi Pastor" (lit. Bloody Pastor) is an ironically humorous nickname given to a Ukrainian politician, Oleksandr Turchynov, a Baptist according to his religious beliefs and a person known for his persistence and inflexibility in the face of the Russian aggressor.

${ }^{2}$ During the 2012 election campaign a meme borrowed from a random billboard in the town of Kamianske (formerly Dniprodzerzhynsk) showing an old woman with a cat gained wide popularity. The billboard was created as a part of an anti-campaign against Partiya Rehioniv [lit. The Party of the Regions]. The slogan under the picture said (TN) "Learnt that my grandson had voted for Partiya Rehioniv and left the house to the cat". The image has become an independent meme, as well as giving rise to a string of doctored pictures and demotivational posters.
} 
meme as a repository of cultural signs, as well as an intellectual by-product of the collective creative genius of the internet community, which consists of a verbal part (a text) and a paralinguistic part (an image), along with mutually generated ideas of the online community (Dziubina, 2016, p. 379).

Doctored images by Bohdan Protsyshyn ${ }^{3}$ have garnered attention due to their professional, artistic, and content-rich execution in which the creator focuses on current socio-political events. His most well-known series of works depict Ukrainian politicians as characters from the popular fantasy TV series Game of Thrones and portray them on various hryvnia denominations. The series Tales from Around the World is dedicated to the insignia and paraphernalia of political leaders. The series Reading Podrevianskyi Together (TN. Les' Podrevianskyi is notorious for his expletive-laden works) has photos of politicians complemented by quotes from his book. The Easter series is a set of doctored images picturing Easter eggs embellished with party insignias (TN. Ukraine is known for its tradition of lavishly decorated Easter eggs, also known as pysanky).

Recently, a substantial number of memes on social media sites have appeared which "contribute to the formation of an all-Ukrainian identity through the use of the consolidating potential of the state language, the updating of archetypes, cultural values, the realization of a common historical heritage, national religion and national heroes, and social content for the myth of the national idea" (Khraban, 2018, pp. 80-81). Protsyshyn's series Mudrist' narodnykh [lit. Folk Wisdom] contains, in addition to photos of political leaders, aptly chosen or paraphrased sayings which characterize the politicians' work or key moments from their professional career: under the picture of Iuliia Tymoshenko there is the saying "Vid tiurmy $i$ vid sumy ne zarikaisia" ("Don't be so sure the life of a beggar or the life of a convict will walk past you") (about her time spent in prison); Oleh Tiahnybok - "Bachyt kit salo, a syly malo" (lit. "A cat sees the lard, but it's out of its reach" alluding to the Svoboda [Freedom] party not having enough votes to get into parliament); Andrii Sadovyi - "Groshi ne pakhnut" (lit. "Money has no smell" - a reference to the problem of garbage disposal in Lviv); Mykola Azarov — "I u Vidni ie liudy bidni" (lit. "There are poor people even in Vienna" - about his time abroad and attempt to still receive a Ukrainian government-issued pension); Nadiia Savchenko - "Movchannia — zoloto" ("Silence is golden" — an allusion to her excessive presence in the media); Ihor Kolomoiskyi — "Kozak nation forever" (a play on words: in the original Ukrainian version the saying goes "Kozatskomu rodu nema perevodu", which literally means "The kozaks cannot be transferred": a reference to Mr. Kolomoiskyi's banking business, particularly to the money transfer service provided by Privat Bank) (Denysiuk, 2016, p. 27).

The relevance of the study of memes is dictated, first and foremost, by their unique features: a modern meme (unlike memes that originated in the pre-internet era) has a particularly short "period of decomposition" - it appears instantly, transforms within a few days (sometimes hours), and just as quickly loses its appeal. In contrast to modern European and American studies, in Ukraine the study of memes remains sporadic. From a purely linguistic perspective, memes are rarely examined. In most cases academic interest is directed at the study of memes with respect to their cognitive or cultural aspects. Publications in Ukrainian dedicated to this topic focus mainly on the internet meme and its verbal and visual incarnations (Piddubnyı, 2011). The linguistic aspect of the study of memes is presented in works by Chernikova, who formulated the criteria of identification and characteristics of memes, additionally presenting a classification of the phenomenon (Chernikova, 2015).

The following criteria are important to the present study: a meme appears spontaneously (in the modern context its appearance can be easily tracked on the internet) (Shchurina, 2015); any item of information can become a meme: an apt word, phrase, image or any other verbal/nonverbal symbol (Deacon, 1999) ; a meme carries more information than appears on the surface (it "refers" to a whole situation, the sum total of its constituents is not equal to its meaning); the internet is currently the best medium for memes, where they spread horizontally, not vertically as was the case before (for example, collocations were passed from generation to generation). However, memes quickly disappear from the information field (Chernikova, 2015, p. 356).

\footnotetext{
${ }^{3}$ For more details follow this link: https://www.facebook.com/Protsyshyn0fficial/?ref=page_internal
} 


\section{Constructing the image of a political opponent in internet memes}

Internet folklore has become a part of political campaign tools and black and white PR. It pulls the necessary strings to appeal to voters' feelings, presenting everything in sharp contrast while touching upon painful topics (Ivanchenko, 2019). The importance of an individual politician is reduced through ridicule in internet memes, turning a politician into a comic character, no longer to be taken seriously and with a low level of trustworthiness. The line where creativity stops and negative PR starts becomes blurred. Memes have divided the society into 'us' and 'them', 'friends' and 'foes', 'porokhobots' (TN. Supporters of Poroshenko) and 'zelenophils' (TN. Supporters of Zelenskyi) (Ivanchenko, 2019).

The presidential candidate Petro Poroshenko is presented in political meme culture as a person who suffers from alcohol abuse.

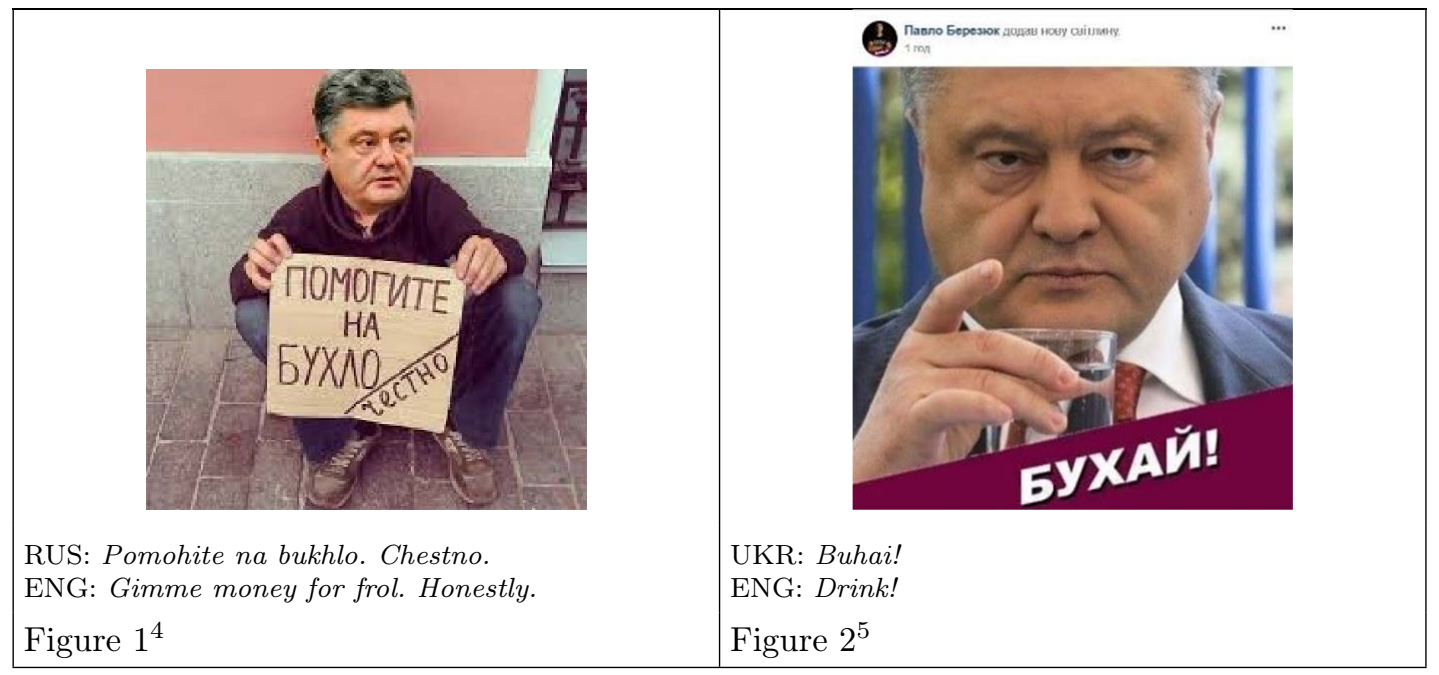

In both memes, the verb 'bukhaty' [lit. get really drunk] (Stavyts'ka, 2005, p. 73) is used, having originated in criminal jargon and later becoming acquired by youth slang. In the second meme, the imperative 'Bukhai!' (lit. Get really drunk) is used, which is a reference to Petro Poroshenko's presidential slogan 'Dumai!' (lit. Think!). In this way, the appearance of an emotional component and a play on words has helped the meme to transcend from a serious and important tone to a mocking one.

Humour and satire are the main features of internet art. Items to be liked and shared have to be brief, clear, relevant, and funny (Ivanchenko, 2019). Apart from the functional ability of an internet meme to instantly replicate itself, it is worth mentioning that these communicative units are also of a mostly ironic nature. Considering the affection of the internet audience for the culture of popular humour (banter, pulling somebody's leg, sarcasm), meme-like messages of an ironic nature are particularly popular on the internet. Researchers stress the sanatory function of memes, their ability to casually discuss serious political issues (Shomova, 2015, p. 37). Moreover, memes provide an opportunity to make fun of an opponent and laugh at a traumatic situation, softening its painful impact and helping to deal with internal tension (Karpiak, 2014).

While Petro Poroshenko is portrayed as having a drinking problem, Volodymyr Zelenskyi is depicted as a drug addict in memes. The origin of these memes can be found in a statement by Oleksandr Palii. This political expert, relying on the expertise of medical experts on drug abuse,

\footnotetext{
${ }^{4}$ http://sensei-yoda.blogspot.com/2015/09/blog-post_486.html

${ }^{5}$ https ://www . uaportal.com/news/ne-vzdumaj-v-seti-izdevayutsya-nad-reklamoj-poroshenko-foto.htm
} 
was confident that Zelenskyi was under the influence of prohibited psychotropic drugs after seeing him on TV (Kutsenko, 2019).

The neologism 'ZeNarik' [lit. the Drug Abuser] became widely popular on the internet. The word was coined with the help of the prefix $Z e$ - (the first two letters of the surname Zelenskyi), which proved efficient in campaign slogans such as 'Ze!President', 'Ze!Deputat' [lit. the Deputy] and so on, ${ }^{6}$ and the Russian word 'narik' [Ukr. 'narkoman'; lit. a drug addict]. The verbal component of one of the memes was taken from the chorus of the song Narkomany na Horodi [lit. Drug Addicts in the Garden] by the Ukrainian band Braty Hadiukiny. ${ }^{7}$ The use of a recognizable musical refrain increases the popularity of a meme, introduces irony into it, and also reflects the attitude to the character: "Yak pobachysh narkomana, byi yogo yak tarakana" [lit. "When you see a drug addict, smash them like cockroaches"].

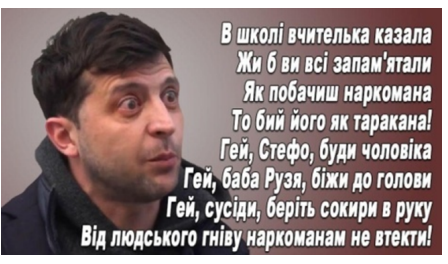

UKR: V shkoli vchytel'ka kazala Zhy by vsi zapamiataly Iak pobachysh narkomana To byi ioho iak tarakana!

Hei, Stefo, budy cholovika

Hei, baba Ruzia, bizhy do holovy

Hei, susidy, berit' sokyry v ruku

Vid liuds'koho hnivu narkomanam ne vtekty!

ENG: A teacher used to say at school

For all of us to remember

When you see a drug abuser

Smash them like a cockroach!

Hey, Stefa, wake your husband up

Hey, grandma Ruzia, run to the village head

Hey you, neighbours, grab some axes

Drug abusers will not flee from human anger!

Figure $3^{8}$

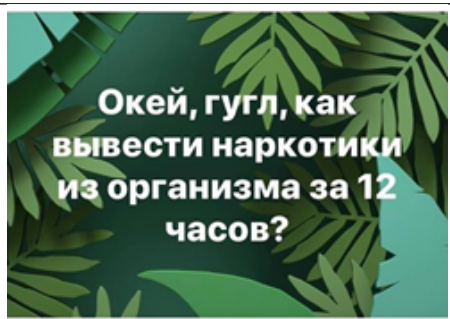

RUS: Okei, gugl, kak vyvesti narkotiki iz organizma za 12 chasov?

ENG: Okay, Google, how do you get drugs out of the body in 12 hours?

Figure $4^{9}$

From the point of view of psychology, memes are a certain type of cultural symbol which reflect polarity between groups: "By humiliating an opponent we make ourselves superior to him, they [opponents] shrink in size, become weak, and we feel power and strength" (Karpiak, 2014). This is the reason why making fun of Volodymyr Zelenskyi's intellect has become one of the key motives for creating memes. The presidential candidate appears weak, unable to express his thoughts or answer simple questions. In this manner his opponents were highlighting that he lacked appropriate experience. Through comedy, mockery, and at times the sarcastic belittling of one's opponent, the mechanisms of negative PR are visible.

\footnotetext{
${ }^{6}$ More details can be found on the official website of Volodymyr Zelenskyi and his team. https://ze2019.com

${ }^{7}$ Braty Hadiukiny — an iconic Ukrainian rock band formed in 1988 in Lviv; they were one of the first bands to gain popularity in the former USSR and the post-Soviet countries.

${ }^{8}$ https://24tv.ua/naysmishnishi_memi_tizhnya_chuvachi_tak_chuvachi_epopeya_z_analizami_i_ litayucha_korova_n1137724

${ }^{9}$ https://censor.net.ua/ua/news/3121035/ne_destabilizuyite_krayinu_bezdiyalnistyu_parlamentu_ vymagayemo_vid_deputativ_zalyshyty_vybory_burbak
} 


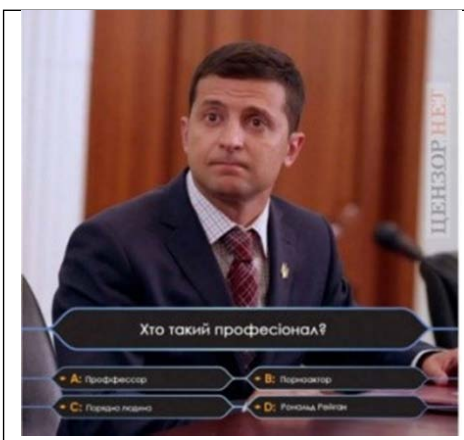

UKR: Hto takyi professional?

A. Profesor

B. Poriadna liudyna

C. Pornoaktor

D. Ronald Reigan

ENG: Who is a professional?

A. Professor

B. An honest person

C. A pornstar

D. Ronald Reagan

Figure $5^{10}$

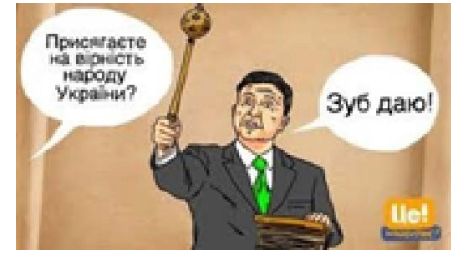

UKR: - Prysiahaiete na virnist' narodu Ukrainy?

- Zub daiu!

ENG: - Do you swear allegiance to the people of Ukraine?

- I bet! (lit. I give my tooth)

Statements by politicians which are accompanied by slips of the tongue and language blunders become explosive material for creative internet users. Ukrainians mocked Zelenskyi's Skype interview during a political talk-show in which, answering the host's question about whether he would turn up on the show in person, Zelenskyi briefly replied: "Zub dayu" [lit. "I give my tooth"] (TN. An idiom which is used to say "I promise"). This language blunder later became a logical addition to creolized texts.

During the presidential campaign, Zelenskyi's image of a comedian and a parody actor was exploited on the internet. ${ }^{13}$ He was referred to as a clown, someone whose behaviour resembles that of a jester. By using derogative labels against an opponent, the other candidate gains certain benefits in their own eyes.

RUS: Ya poshulil, ya zhe kloun
ENG: I made a joke, I'm a clown
Figure $8^{14}$ $\begin{aligned} & \text { UKR: } 1 \text { kvitnia - osoblyva data dlia peremohy } \\ & \text { klouna. } \\ & \text { Figure } 9^{15}\end{aligned}$

While Volodymyr Zelenskyi is depicted as an inexperienced candidate without any political background, Petro Poroshenko is shown as a leader who did not bring any good to the country,

\footnotetext{
${ }^{10}$ https://vybory.depo.ua/ukr/polya/naysmishnishi-memi-pro-zelenskogo-20190402941463

${ }^{11}$ https://24tv.ua/naysmishnishi_memi_tizhnya_zelenskiy_rozdaye_zubi_rap_vid_sadovogo_potyag_do_ shapok_poroshenka_n1120997

${ }^{12}$ https://vybory.depo.ua/ukr/polya/naysmishnishi-memi-pro-zelenskogo-20190402941463

${ }^{13}$ Before becoming the President, Volodymyr Zelenskyi used to be known as a popular comedian, showman, actor and head of the Kvartal 95 studio.

${ }^{14}$ https ://www .meme-arsenal .com/create/meme/1902639

${ }^{15}$ https://www.pravda.com.ua/articles/2019/01/21/7204341/
} 
acted without good reasoning, and abused his position. In this way, Poroshenko's political experience was used against him in the meme war. Most frequently, the then President was referred to by two labels: a looter and a criminal. The negative connotations of these lexical units have contributed to creating a certain image of the politician, adding a tone of disrespect, overfamiliarity and condemnation.

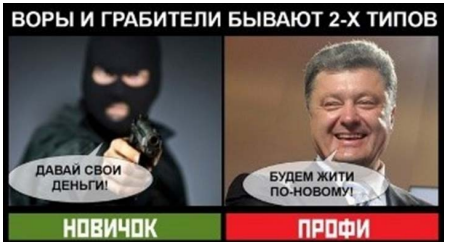

RUS/UKR: Vory I grabiteli byvaiut 2-h tipov: Davai svoi den'gi! - Novichok. Budem zhyty po-novomu! Profi.

ENG: Thieves and burglars can be of two types: Give me your money! - A newbie (left). We'll be living a new life. - A professional (right).

Figure $10^{16}$

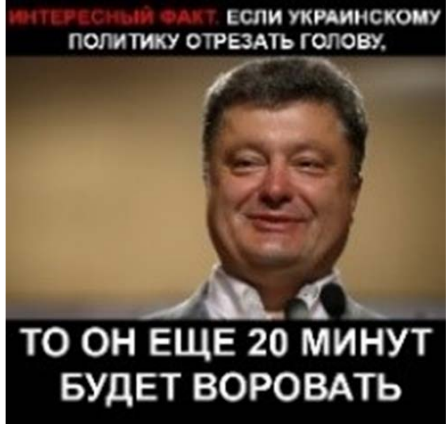

RUS: Interesnyi fakt: iesli ukrainskomu politiku otrezat' golovu, to on ieshche 20 minut budet vorovat. ENG: An interesting fact: If you cut off the head of a Ukrainian politician, he'll keep stealing for another 20 minutes.

Figure $11^{17}$

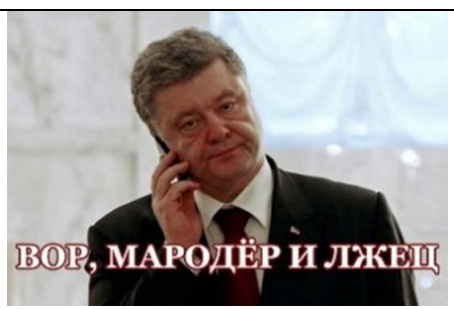

RUS: Vor, maroder $i$ lzhets.

ENG: A thief, a looter, and a liar.

Figure $12^{18}$

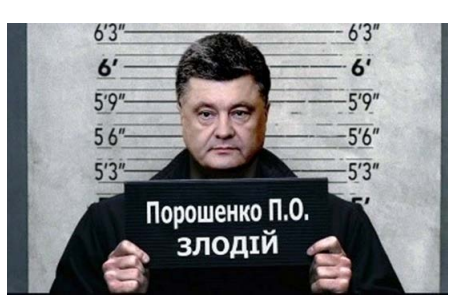

UKR: Poroshenko P.O. Zlodii.

ENG: Poroshenko P.O. A thief.

Figure $13^{19}$

It is worth noting that the verbal component of the memes mocking Poroshenko were most frequently presented in Russian. In one meme, a Kremlin propaganda statement is used saying that it is Ukrainian soldiers who are attacking the Donbas ${ }^{20}$ : "And what if in order to resolve Ukraine's

\footnotetext{
${ }^{16}$ https://dosie.su/politika/29061-protiv-vorovatogo-eks-diktatora-poroshenko-vozbuzhdeno-treteugolovnoe-delo.html

${ }^{17}$ https://www.pinterest.de/pin/282319470370477444/

${ }^{18}$ https://twitter.com/proro2012/status/1100647692852707328

19 http://imtw.ru/topic/32542-pyotr-poroshenko-vor-lzhec-i-marodyor/page__st__140

${ }^{20}$ During the talks between the four heads of states in Minsk, Belarus on February 11th 2015, an accredited journalist from the Russian TV channel Rossiya [Russia] was escorted out of the Palats Nezalezhnosti [TN. The Independence Palace] through the back door after he had started shouting to Petro Poroshenko "Why are your soldiers bombing peaceful civilians?"

A Russian TV channel Ulybka rebionka [TN. Kid's Smile] has shown a pseudo-pacifist video in which the Ukrainian army was allegedly bombing the Donbas. The video starts with children's drawings depicting peaceful life destroyed, as the authors of the film claimed, by the Ukrainian army. The video tries to convince that it was the Ukrainian army who were bombing the towns and peaceful residents of the Donbas. A ticker under the video says: "Save the Donbas citizens from the Ukrainian aggression". For more details see: In Russian they are showing children cartoons about the Ukrainian army bombing the Donbas ( U Rosiï pokazaly mul'tfil'm, iak ukraïns'ka armiia bombyt' Donbas, 2014).
} 
problem, it is necessary to stop bombing the Donbas". Some of the memes about Poroshenko which were popular on the internet were created on Russian domains, for example, meme-arsenal.ru and vk.com, evidence of which is presented via watermarks.

\begin{tabular}{|c|c|}
\hline $\begin{array}{l}\text { ДАНЕ, БРЕДसमसИ-ТО } \\
\text { RUS: A chto iesli dlia resheniia problem Ukrainy nu- } \\
\text { zhno prekratit' bombit' Donbass, zaniatsia resheniiem } \\
\text { ekonomicheskih problem, a ne prosto blokirovat' soc- } \\
\text { seti? Da ne, bred kakoi-to. } \\
\text { ENG: What if in order to resolve Ukraine's problem, } \\
\text { it's necessary to stop bombing the Donbas, to start sol- } \\
\text { ving economic problems, not just blocking social me- } \\
\text { dia? No, it's a bullshit. } \\
\text { Figure } 14^{21}\end{array}$ & 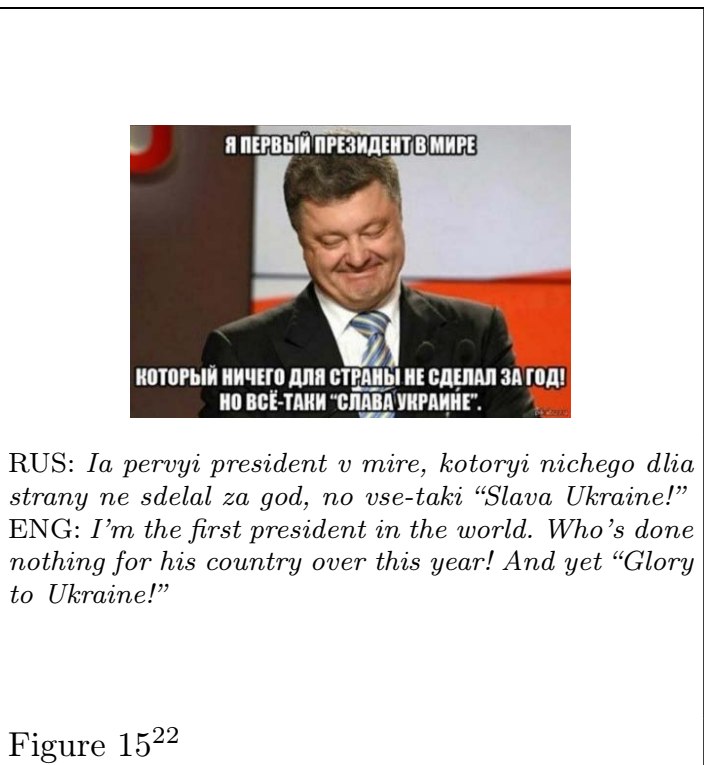 \\
\hline
\end{tabular}

Poroshenko's opponents also exploit the fact that while being President he signed a law which legally fixes the greeting "Slava Ukraini!"23 [lit. "Glory to Ukraine!"] for the army and the police, and which is considered his only 'achievement'. Meme writers thus ironically talk about the slogans which Poroshenko used in his speeches. They (his opponents) stress the populist statements by the then President.

The memes in which both opponents are presented simultaneously is identified as a separate group. In this manner, a stereotypical image of the other candidate is formed. Against the background of the opponent, the other candidate's image appears to be right and attractive.

\footnotetext{
${ }^{21}$ https://memepedia.ru/socseti-otvetili-memami-na-blokirovku-vkontakte-v-ukraine/

${ }^{22}$ https://ua.korrespondent.net/ukraine/politics/3523817-litopysni-obry-movu-poroshenka-vysmiialy$\mathrm{v}$-memakh9

${ }^{23}$ For more details see 'Poroshenko signed a law which fixes the greeting "Slava Ukraini" [lit. "Glory to Ukraine"] for the army and the police' (Poroshenko pidpysav zakon, 2018).

The slogan "Slava Ukraini" [lit. "Glory to Ukraine"] and the reply "Po vsii zemli slava!" (lit. "Glory Around the World") was first used among students in Kharkiv at the end of the $19^{\text {th }}$ century. It was the same group of students which gave rise to the Revoliutsiina Ukrainska Partiia (RUP) [TN. Revolutionary Ukrainian Party] in 1900 — the first modern Ukrainian party under the Russian jus primae occupationis. The first known mention of the slogan is linked to this community. For more detail see: IUzych, 2018.
} 


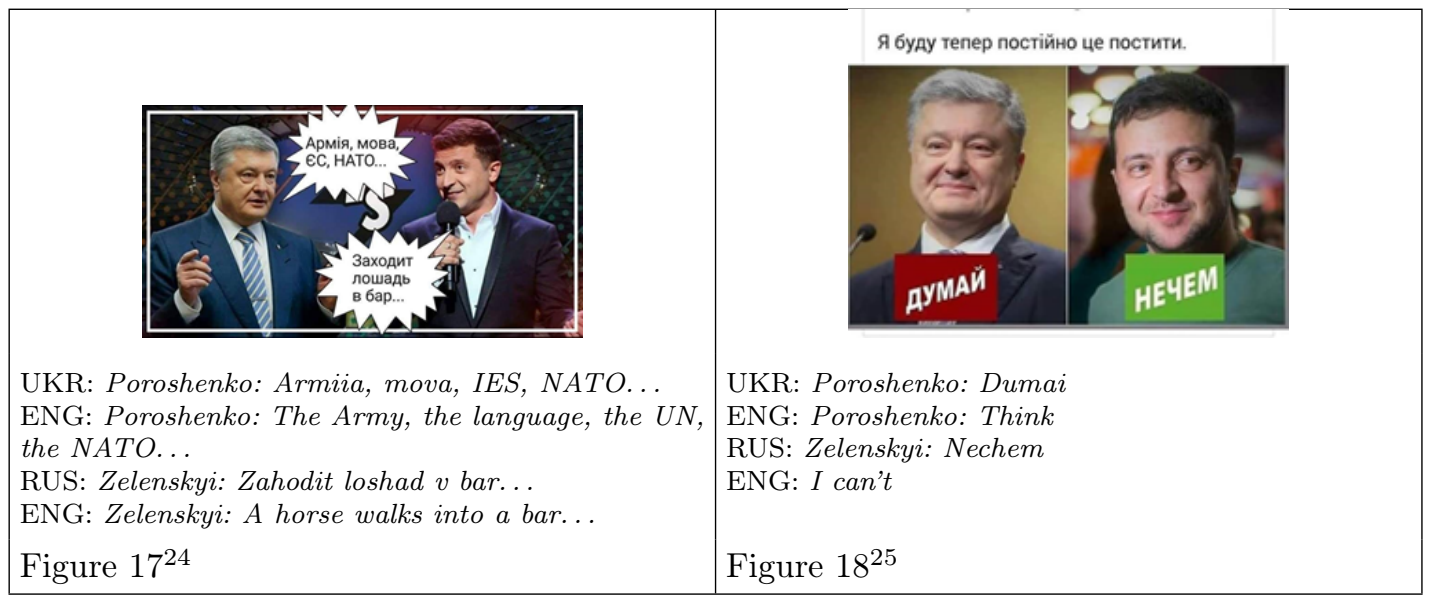

Petro Poroshenko, for example, mentions the values and points at the keystones which each Ukrainian can relate to - the army, the language, the UN and the NATO. This has become a key slogan in Poroshenko's presidential campaign. Meanwhile, Volodymyr Zelenskyi is depicted as a comedian who can only reply to political slogans with a clumsy Russian joke. Even if the meme characters are shown in a relatively neutral manner, when it comes to gaining the audience's sympathies the images of these people become rather dubious.

\section{The polarisation of Ukrainian society in the mirror of me- mes}

The highly emotional debates surrounding the 2019 presidential election in Ukraine demonstrated that Ukrainian society is deeply polarised. Society was divided into two parts - supporters of the current President Volodymyr Zelenskyi, who won the elections with the overwhelming majority of votes - 73,22\%, and supporters of the former President Petro Poroshenko, who lost with 24,45\% of votes. Naturally, this polarisation was embodied and visualised in social media. For instance, many supporters of Poroshenko added frames to their profile pictures on Facebook with his slogan Dumay! [Think!], then later changed it to 25\%, thus indicating their political views and choices. In contrast, supporters of Zelenskyi often use frames with his symbolic green colour and the slogan Ze! [Ze!]. Social media served to intensify and deepen this polarisation. As many media experts noticed, social media were extremely important in these elections, appealing mainly to voters' emotions and becoming an instrument of social polarisation (Skliarevskaia, 2019). Moreover, one of the main communication strategies of both candidates was to discredit his opponent (Skliarevskaia, 2019), making polarisation inevitable. Consequently, Suschuk warns about the dangers of such campaign strategies: "Such a choice, when one side is imagined as unambiguously good, and the other evil, polarises the society. Communicative bridges are ruined, misunderstanding grows, argumentative comments are turned into emotional outbursts" (Sushchuk, 2019).

Nevertheless, in numerous memes polarisation as a social problem was highlighted with a great degree of humour. The authors of memes used various images and texts for their creation. For instance, medieval pictures, popular for meme design in the Ukrainian segment of the internet, were used, as were popular memes from Western culture. The aim of these memes was, in a humorous way, to show clashes between supporters of different candidates and to hyperbolize the involvement of Ukrainian citizens in the election race and the politicisation of Ukrainian society. They played on family disagreements, such as the meme depicting a woman who is concerned that her husband

\footnotetext{
${ }^{24}$ http://pplus.in.ua/news/zelenskiy_vs_poroshenko_v_merej_shiryatsya_sm_shn_memi_naperedodn_debat_ $\mathrm{v}$

${ }^{25}$ https://www.facebook.com/Dmitriy.Chekalkin/posts/4191478670878354
} 
pays attention only to politics, or a cartoon template was used to show the family life of people with different political views.

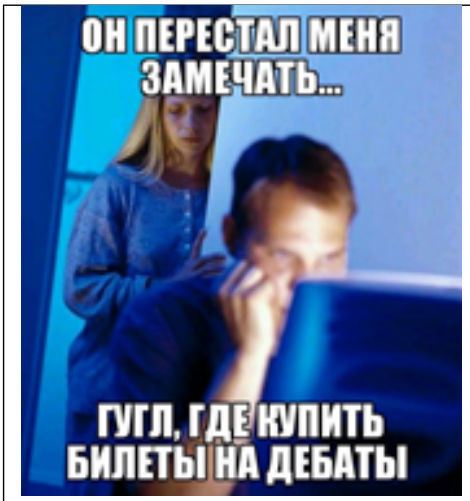

RUS: On perestal menia zamechat '...Gugl, gde kupit' bilety na debaty?

ENG: He stopped to notice me..

Google, Where could I buy tickets

for debates?

Figure $19^{26}$

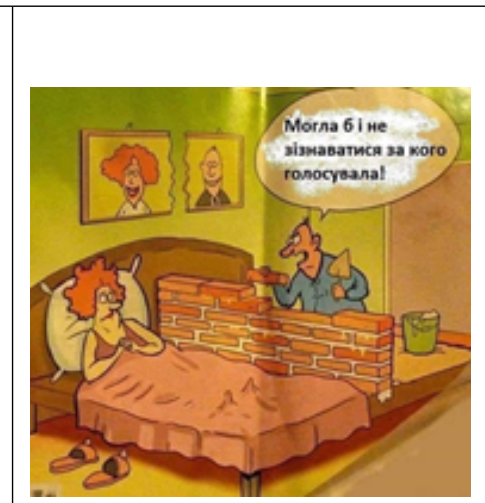

UKR: Mohla $b$ I ne ziznavatysia za koho holosuvala!

ENG: You could have not confess for whom you voted!

Figure $20^{27}$

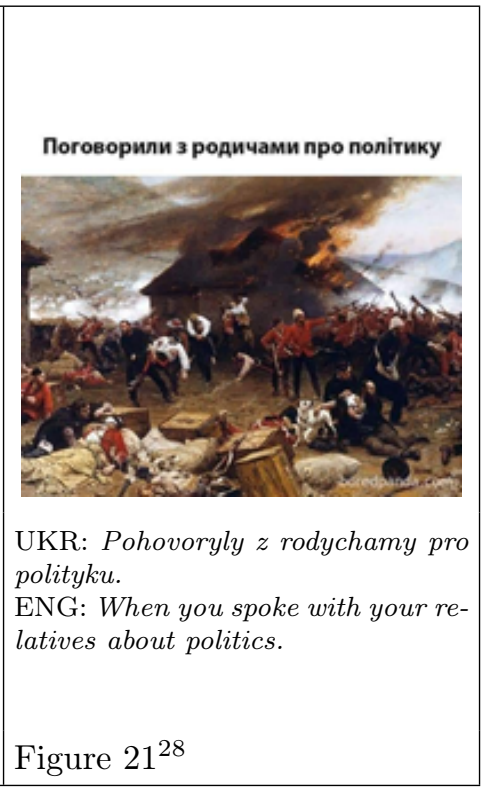

Figure $21^{28}$

Some memes also described broader societal conflicts. For these memes the authors used medieval pictures. The aim of these memes was to convey the message that the politicisation of society is deepened and manipulated by the media, in particular by social media.

\begin{tabular}{l} 
UKR: Koly vyrishyly pohovoryty pro vybory. \\
ENG: When you decided to speak about the elections. \\
$\begin{array}{l}\text { Ekeisbuku na kil'ka dniv. } \\
\text { ENG: What a stadium? What analyses? When you } \\
\text { have not used Facebook for a few days. } \\
\text { Figure } 23^{30}\end{array}$ \\
\hline
\end{tabular}

By using popular memes from Western culture, the authors receive a special communicative bonus: they give the audience familiar material while at the same time shifting its focus. As a result, this contradiction causes a humorous effect. For instance, the popular meme Batman

\footnotetext{
${ }^{26}$ http://pplus.in.ua/news/zelenskiy_vs_poroshenko_v_merej_shiryatsya_sm_shn_memi_naperedodn_debat_ $\mathrm{V}$

${ }^{27}$ https://33kanal.com/news/59148.html

${ }^{28}$ http: //gadzzilla.org/pogovorili-z-rodichami-pro-politiku-2/

${ }^{29}$ https ://apostrophe.ua/ua/news/politics/elections/2019-04-05/poroshenko-protiv-zelenskogoluchshie-memyi-i-fotojabyi-nedeli/159322

${ }^{30}$ https : //www. obozrevatel. com/ukr/curious/prezident-pochinaetsya-z-analiziv-ukraintsi-pidirvalimerezhi-memami-na-batl-poroshenka-i-zelenskogo.htm
} 
slapping Robin, which was originally published in a DC comics book in the $1960 \mathrm{~s}^{31}$ and was used as template for numerous parodies in different contexts, was applied during the Ukrainian presidential elections as well. In the Ukrainian political interpretation of the meme Batman speaks in the Western Ukrainian dialect, adding an extra layer of humour.

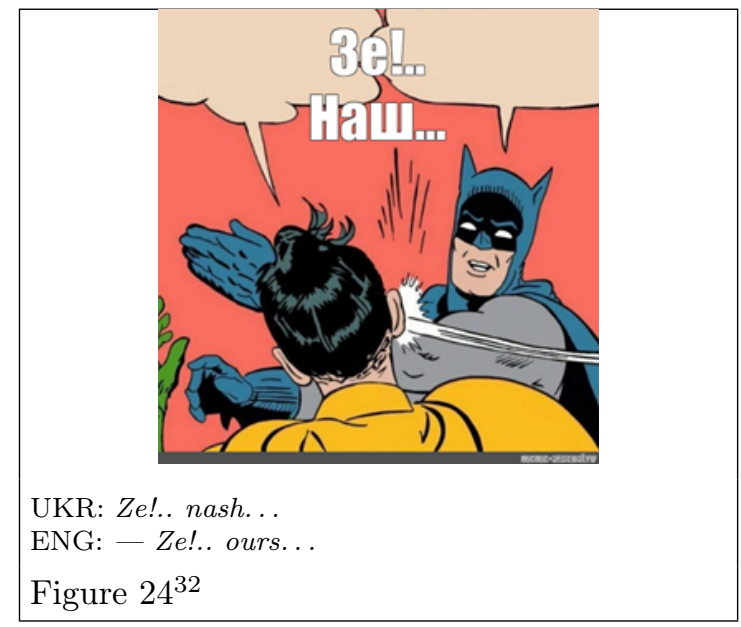

In another comic meme, Three little words, the politicisation of society is again underlined and the great public interest in the presidential debates is alluded to. Another "kiss meme" was created by supporters of Poroshenko. The origin of this meme is the science-fiction film Passengers. One more meme also applies a sexual context, visualising key political players - Poroshenko, Tymoshenko, Zelenskyi - as lovers, with the background hinting to the drama movie American Beauty. These memes therefore correspond to the metaphoric scenario politics is love, which is broadly used in public discourse in the EU (for detail see Mussolf, 2006). By placing political issues in such a context, meme creators attract more attention, simplify complicated problems and turn them into humorous and emotional topics.

\footnotetext{
${ }^{31}$ See for detailed: My Parents Are Dead / Batman Slapping Robin, n.d.

${ }^{32}$ https : //www . meme-arsenal. com/create/meme/922905
} 


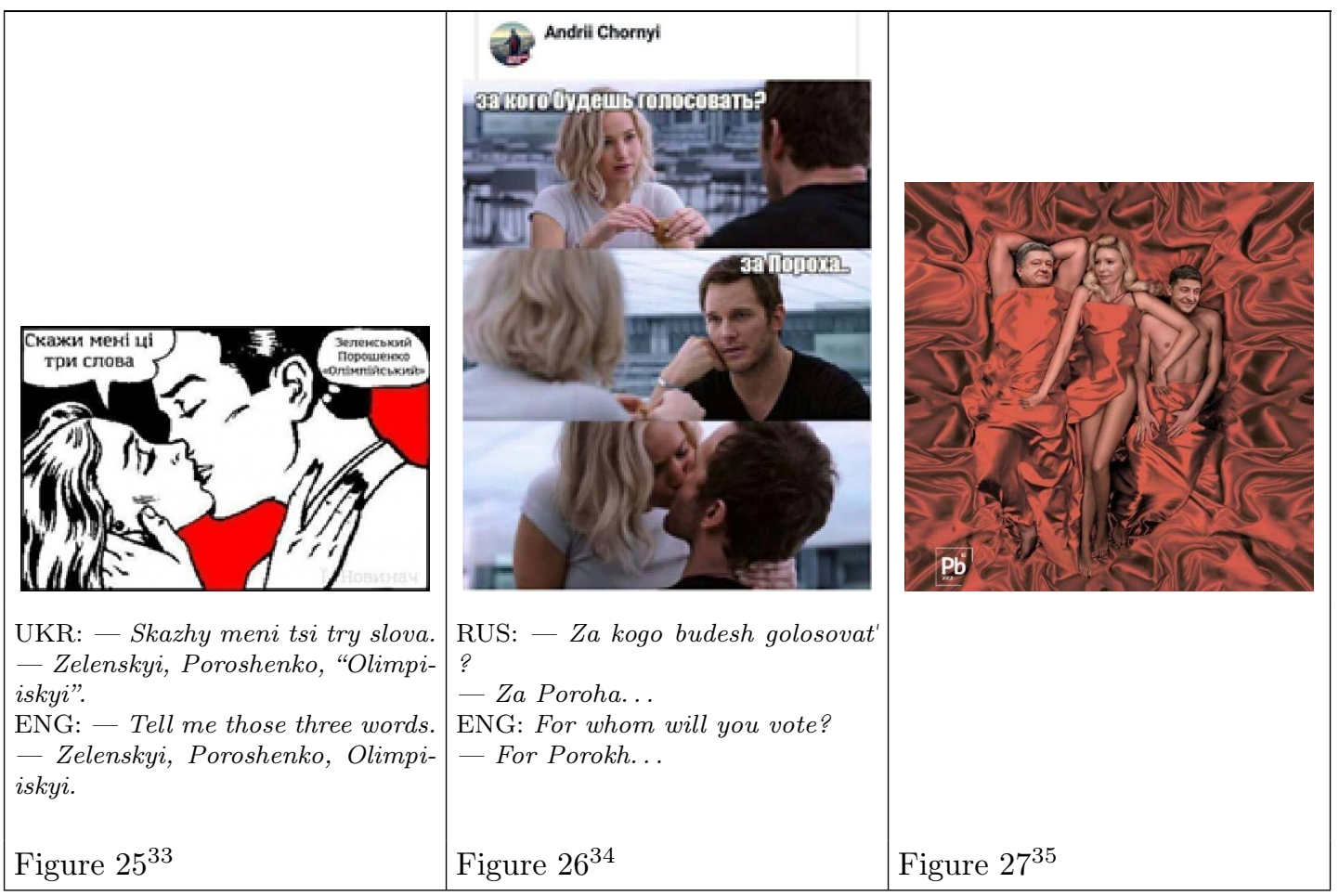

As is demonstrated in previous examples, the same popular meme can be used as a template for the creation of other memes with different meanings and purposes. Similarly, the famous Distracted boyfriend meme, which originally came from a stock photo website and later gained popularity on Facebook and Twitter ${ }^{36}$ is applied to convey diverse messages. In one example, the meme is adapted to show the Ukrainian people (distracted boyfriend) staring at a new girl (Zelenskyi), making the girlfriend (Poroshenko) angry. It was most probably made by Zelenskyi's team or supporters, as it uses a positive visual image of him, in contrast to the negative picture of Poroshenko. This meme has only a visual component, not a textual one, since it is highly recognizable and the meaning is transparent without words.

In another example, a similar template is used to deliver another message: young people in Ukraine are not interested in politics, they are not willing to vote in elections. It should be mentioned that a comparable version of the meme existed previously, demonstrating that young people prefer socialism, not capitalism (Distracted boyfriend, n.d.). This meme could be interpreted in various ways, depending on the target audience and platform on which it appeared. On one hand, it could be understood as a critique of low turnout among young people in elections. On the other hand, it could be seen as discouraging young people to vote and provoking socio-political apathy. In contrast to this second interpretation, a meme with a photo of the actor Leonardo Di Caprio, taken from the film The Great Gatsby, encourages the audience to be politically active. Again, all of these memes are created within the metaphoric scenario politics is love, gaining attention and influencing voters' emotions, and consequently choices.

\footnotetext{
${ }^{33}$ https://apostrophe.ua/ua/news/politics/elections/2019-04-05/poroshenko-protiv-zelenskogoluchshie-memyi-i-fotojabyi-nedeli/159322

${ }^{34}$ https : //fakty.com.ua/ua/lol/20190401-zhart-na-1-kvitnya-krashhi-memy-pro-vybory-2019-ukrayina/

${ }^{35}$ https ://racurs .ua/ua/n120375-analizy-debaty-ta-vybory-vybuhova-reakciya-socmerej-na-batlporoshenka-ta-zelenskogo-foto-video.html

${ }^{36}$ For detailed information see: Distracted boyfriend, n.d.
} 


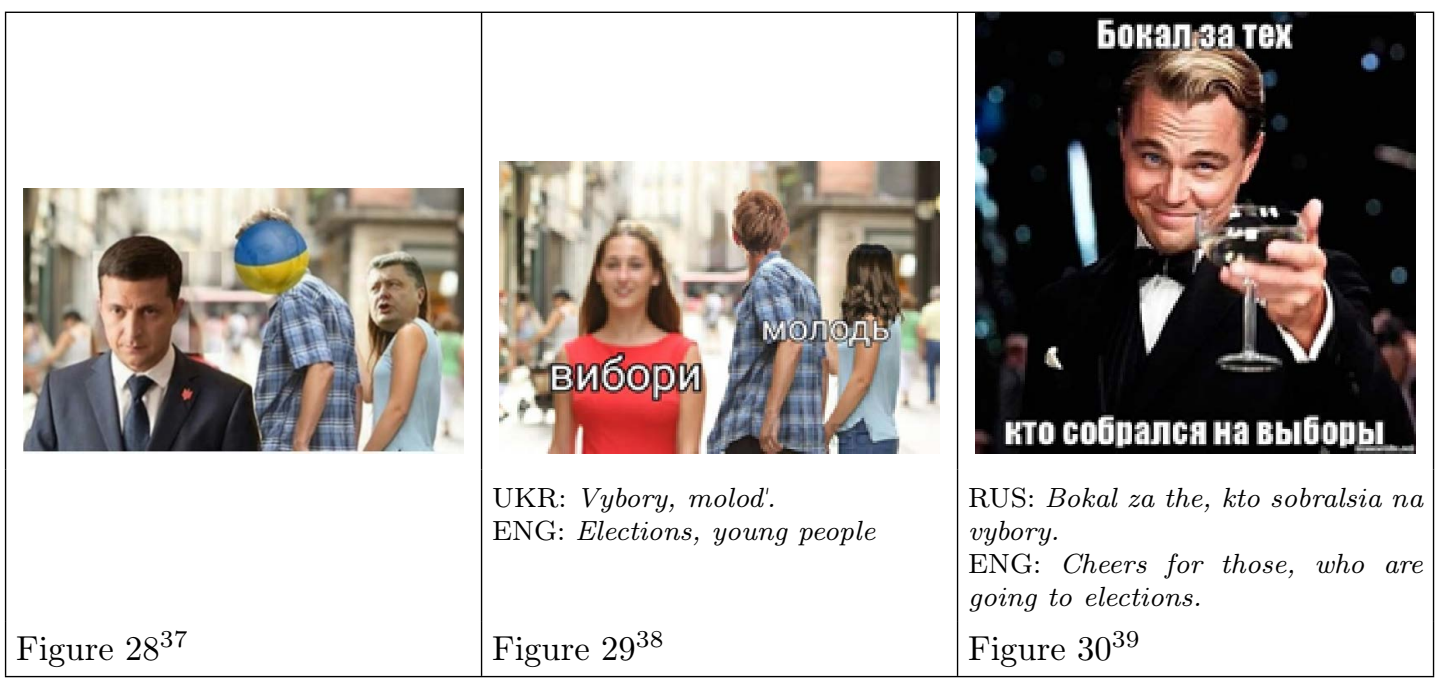

A popular meme which uses monkeys and is often used by Ukrainian internet users demonstrates that society is tired of the political process. The same message is conveyed by another meme, based on the science-fiction film Alien. In both memes the female name Halya is used, which adds further comic effect, since this name was frequently used in folk songs and nowadays is often employed in memes as well. On the other hand, the same image of monkeys is used to deliver a different message. In this meme, the female name Yulya is mentioned, referring to Yuliya Tymoshenko, and describes her as an 'old' politician that, perhaps, still has some potential in the election campaign, if not as successful candidate, then as a mediator. These memes are framed within the metaphoric scenario - politics is an animal world. As research, based on comparative analysis of British and Lithuanian media, has demonstrated, animal metaphors assist in highlighting the division of politicians into strong and weak, where both are led by the instincts for self-protection and aggressive self-defence (Arcimavičienè, 2011). In the Ukrainian context, memes with animal templates are used to describe the polarization of society by underlining the hostility, aggression and dehumanization that often occurs during military conflicts. Moreover, Lung points out that sources for animal metaphors are often not only textualized, but also visualized: "And the power of the animal metaphor is not exclusively linked to the world of the written word. The use of political symbolism and iconography spans from the heraldry of medieval times and royal seals, to the political cartoons of the nineteenth century, pre-war zoomorphic propaganda maps and the colourful fauna of the Economist covers of today" (Lung, 2018, p. 236). Therefore, in this regard political memes which employ animal imagery are more typical examples than single exceptions in public discourse.

\footnotetext{
${ }^{37}$ https://lux.fm/merezhu-rozirvali-memi-na-prezidentski-vibori-2019_n80094

${ }^{38}$ https://fakty.com.ua/ua/lol/20190401-zhart-na-1-kvitnya-krashhi-memy-pro-vybory-2019-ukrayina/

${ }^{39}$ http://memesmix.net/meme/gvt0hx
} 


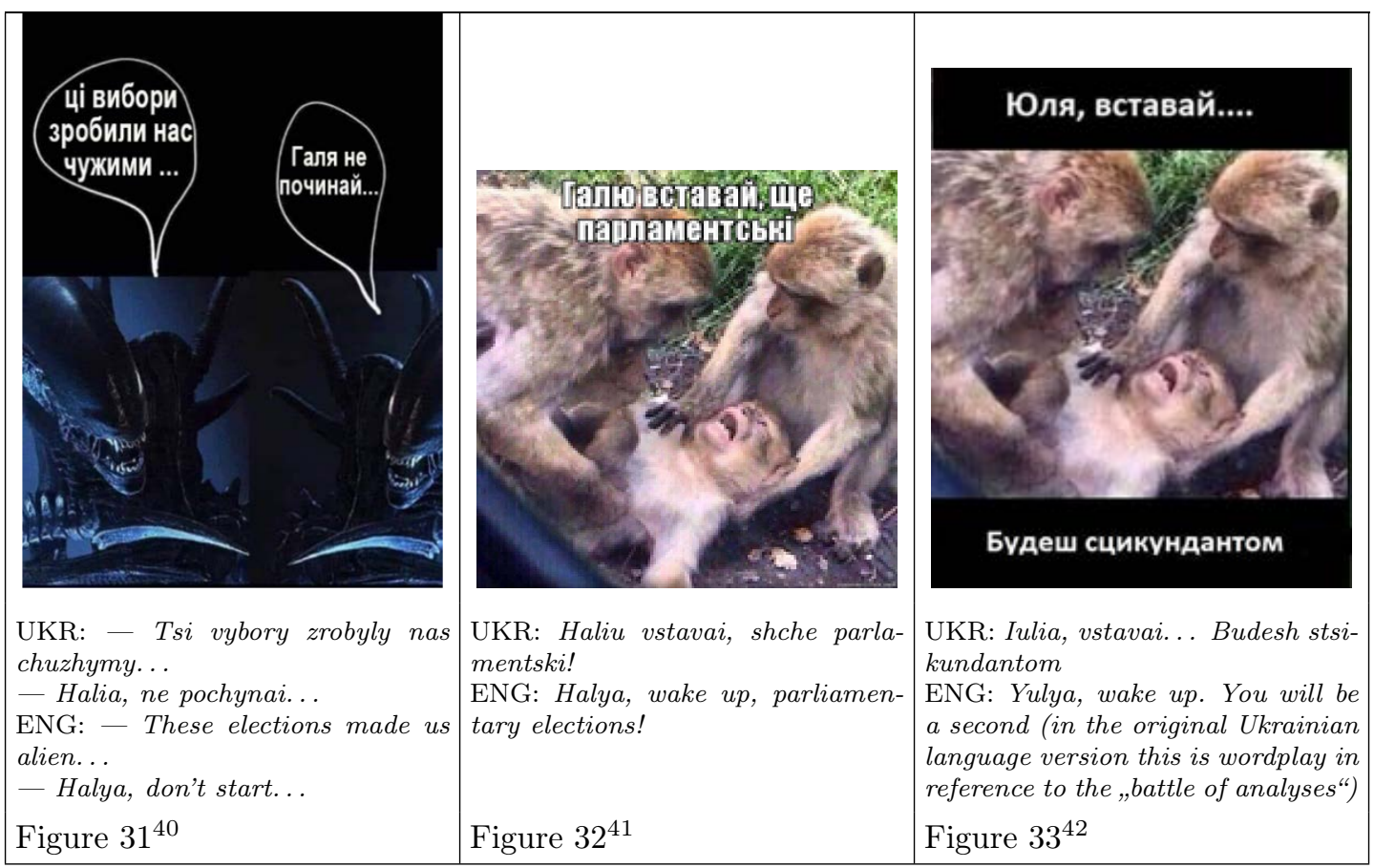

A large group of memes relate to the debate between the main presidential candidates which took place in Kyiv's Olympic stadium. It was an unusual format, proposed by Zelenskyi, whose whole campaign strategy was to represent politics as a performance or show. As Yermolenko notes: "Zelenskyi makes everything into a meme, into a story" (qtd. in Skliarevskaia, 2019). Nevertheless, the challenge was accepted by Poroshenko and nationwide attention was drawn to the event. It would seem that memes about the stadium debate more united country than polarized it. For instance, by comparing an interest in politics with rock fandom, one meme shows some form of national pride. Another meme compared the Olympic stadium with the Colosseum. The photos of Ukrainian pop-stars - Sviatoslav Vakarchuk, Oleh Vynnyk, Mykhailo Poplavskyi — were often used in these memes to demonstrate the great popularity of the event. Moreover, the phrase with which Poroshenko accepted the challenge, "Stadium so stadium", immediately became a meme itself and spawned numerous humorous interpretations.

\footnotetext{
${ }^{40}$ https://www.chasipodii.net/article/22638/

${ }^{41}$ http://memesmix.net/meme/ui7q8e

${ }^{42}$ https://racurs .ua/ua/n120375-analizy-debaty-ta-vybory-vybuhova-reakciya-socmerej-na-batlporoshenka-ta-zelenskogo-foto-video.html
} 


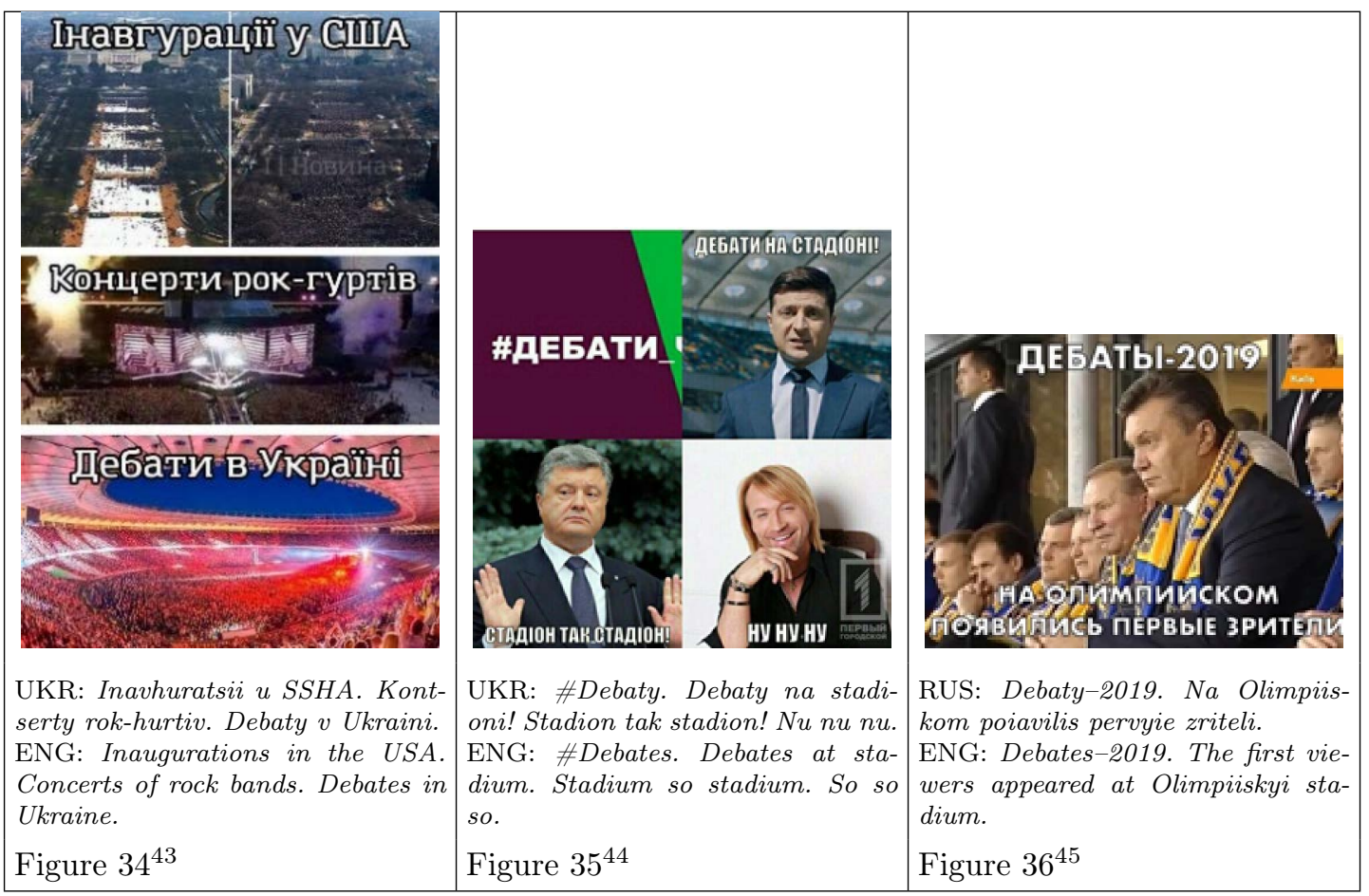

Furthermore, the unusual venue of the debate refers to a widespread metaphorical scenario - politics is sport. This metaphor appears especially dynamic during election campaigns, when presidential candidates are often compared to sport players, and the campaign itself to a sport competition or marathon (for detail see Thu Hang, 2016). In the Ukrainian context, Poroshenko and Zelenskyi were depicted as boxers; in addition, in one meme photos depicting ex-presidents as football spectators were employed to add comic effect. On the other hand, the overuse of sport metaphors in political discourse could be seen as a crucial indicator of the state of civil society: "'... when the media continually describe politics as a game, however, the subtle implication is that the public can only watch rather than participate" (Vieth, 2015, p. 4).

Finally, it is important to mention that the polarisation of Ukrainian society is one of the key tasks of Russian propaganda. For instance, media expert Tetiana Pushnova states: "The media that offers us narratives of Russian propaganda continue to operate successfully in Ukraine. They exerted their influence both through traditional media and through social networks. Their task, apart from strengthening the position of the candidate with the Russian narrative, was to undermine confidence in state institutions and to widen the gap between the strata of Ukrainian society" (qtd. in Skliarevskaia, 2019). Nevertheless, memes about the polarisation of society, created by Ukrainian internet users, were more humorous in nature. Therefore, their main function was to highlight the problem, sarcastically hyperbolize it, and thus assist in its resolution.

\section{Involving the other: the role of Ukrainian politicians in the meme war}

During the pre-election campaign, authors of memes employed the images of some other politicians. This section will focus on memes depicting Iuliia Tymoshenko and Ihor Kolomoiskyi, since these

\footnotetext{
${ }^{43}$ https://lux.fm/debati-zelenskogo-i-poroshenka-2019-memi-rekciya-socmerezh-prikoli-videofoto_n80254

${ }^{44}$ https://one.kr.ua/news/21223

${ }^{45}$ https://apostrophe.ua/ua/news/politics/elections/2019-04-05/poroshenko-protiv-zelenskogoluchshie-memyi-i-fotojabyi-nedeli/159322
} 
groups of creolized texts were most numerous on the internet.

The internet exploded with new memes after Volodymyr Zelenskyi stated that he wanted Iuliia Tymoshenko to play the role of mediator in the presidential debate. All of these verbal-iconic texts can be divided into two groups: Tymoshenko as a referee and Tymoshenko as a host.

Given that the debates took place at the Olympic stadium, Tymoshenko was most frequently depicted as a football referee. In this group of memes one can observe some sexual implications, which are an integral part of any popular culture genre. Iuliia Tymoshenko is presented as an alluring woman who is not afraid to demonstrate her attractiveness. The verbal component of this meme appears rather controversial: "Ya hotova!" [lit. "I'm ready!"] can be interpreted from a sexual point of view, as well as from a political one.

In the final pre-election race, debates ceased to perform their main function and became an excuse for public gatherings. This perception triggered a second type of meme - Tymoshenko as a party host, covering a whole range of occasions: weddings, funerals, christenings, and debates. A visual component is expressed through Tymoshenko's pre-election campaign propaganda, and the verbal one focuses on the politician's campaign pledges. She insisted she would decrease gas prices by half. The memes say that Tymoshenko will host any party for half a price. Transformations of political slogans often become a part of a meme, making these creolized texts even more ironic.

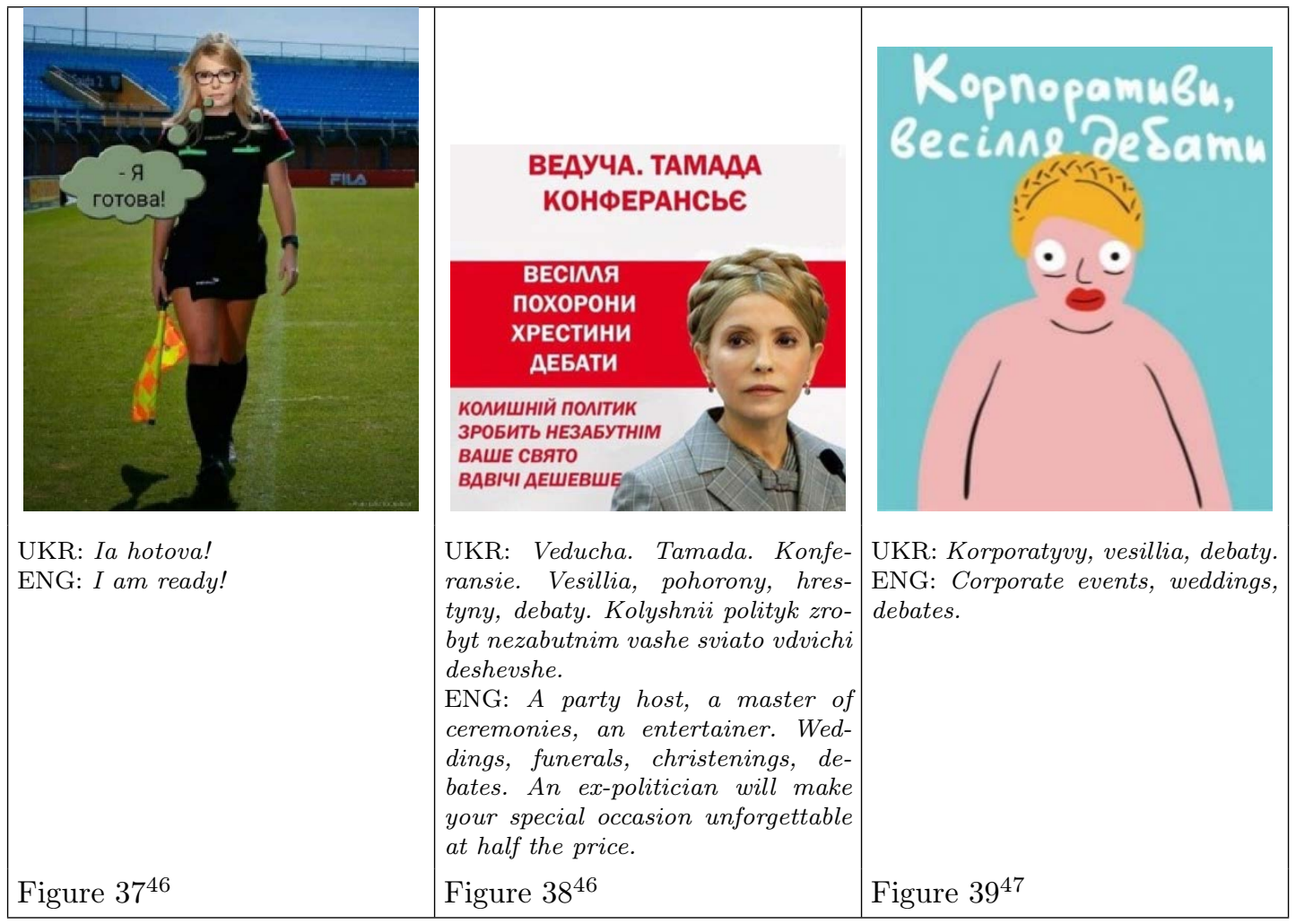

Meme creators also used a widely recognized photo of the politician from the 2010 presidential campaign and a hot Zelenskyi-Poroshenko debate topic. Through the meme, the context of medical tests, which both presidential candidates agreed to undergo publicly before the debates, is explored, as well as the invitation to Tymoshenko to act as a referee during the Olympic Stadium debate.

\footnotetext{
${ }^{46}$ https://apostrophe.ua/ua/news/politics/elections/2019-04-05/poroshenko-protiv-zelenskogoluchshie-memyi-i-fotojabyi-nedeli/159322

${ }^{47}$ https://24tv.ua/naysmishnishi_memi_tizhnya_chuvachi_tak_chuvachi_epopeya_z_analizami_i_ litayucha_korova_n1137724
} 
With the help of internet creativity, the politician turns from a referee into an invigilator during the submission of medical tests.

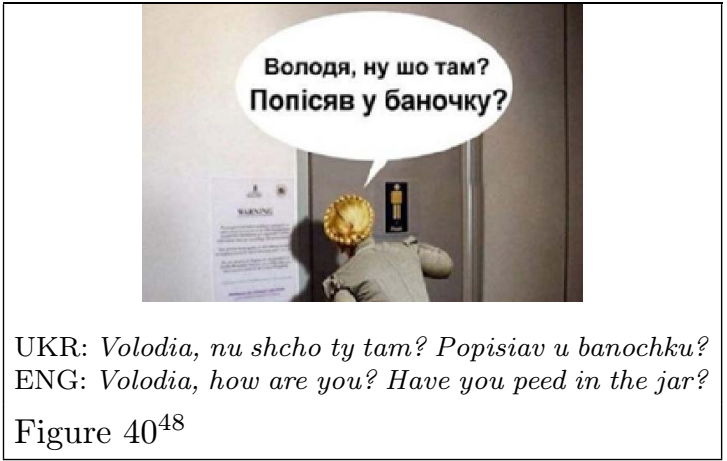

The meme, which corresponds to an earlier image of the politician, was received positively by the audience and actively shared online.

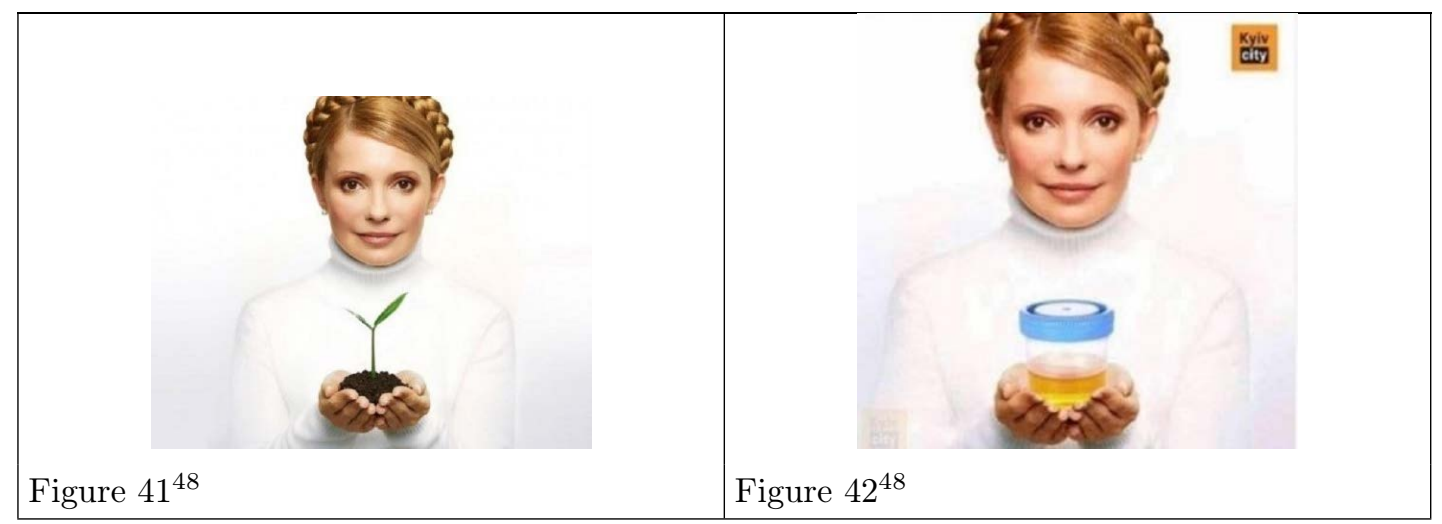

The name of the oligarch Ihor Kolomoiskyi is associated with Volodymyr Zelenskyi. ${ }^{49}$ Hence, memes showing both politicians with respective verbal captions were shared widely on the internet. For example, "Kolomoiskyi - President 2019". In other examples, the verbal component was missing, leaving just the visual one. The motivation in such instances was extremely clear. For example, the meme in which Volodymyr Zelenskyi looks in the mirror and sees the reflection of Ihor Kolomoiskyi. In the third meme the politician's real persona has become a character of the internet meme, having acquired some semi-mythical heroic features. Besides this, the relations between Zelenskyi and Kolomoiskyi are characterized with the sarcasm inherent in memes, in which the latter politician is referred to as "father".

\footnotetext{
${ }^{48} \mathrm{https}: / / \mathrm{ms}$. detector .media/sotsmerezhi/post/22749/2019-04-16-analizi-stadion-oktagon-u-gripolitichni-memi/

${ }^{49}$ For more details see: Zelenskyi and Kolomoiskyi: "Skhemy" (TN Schemes) have revealed three pieces of evidence

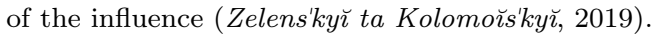




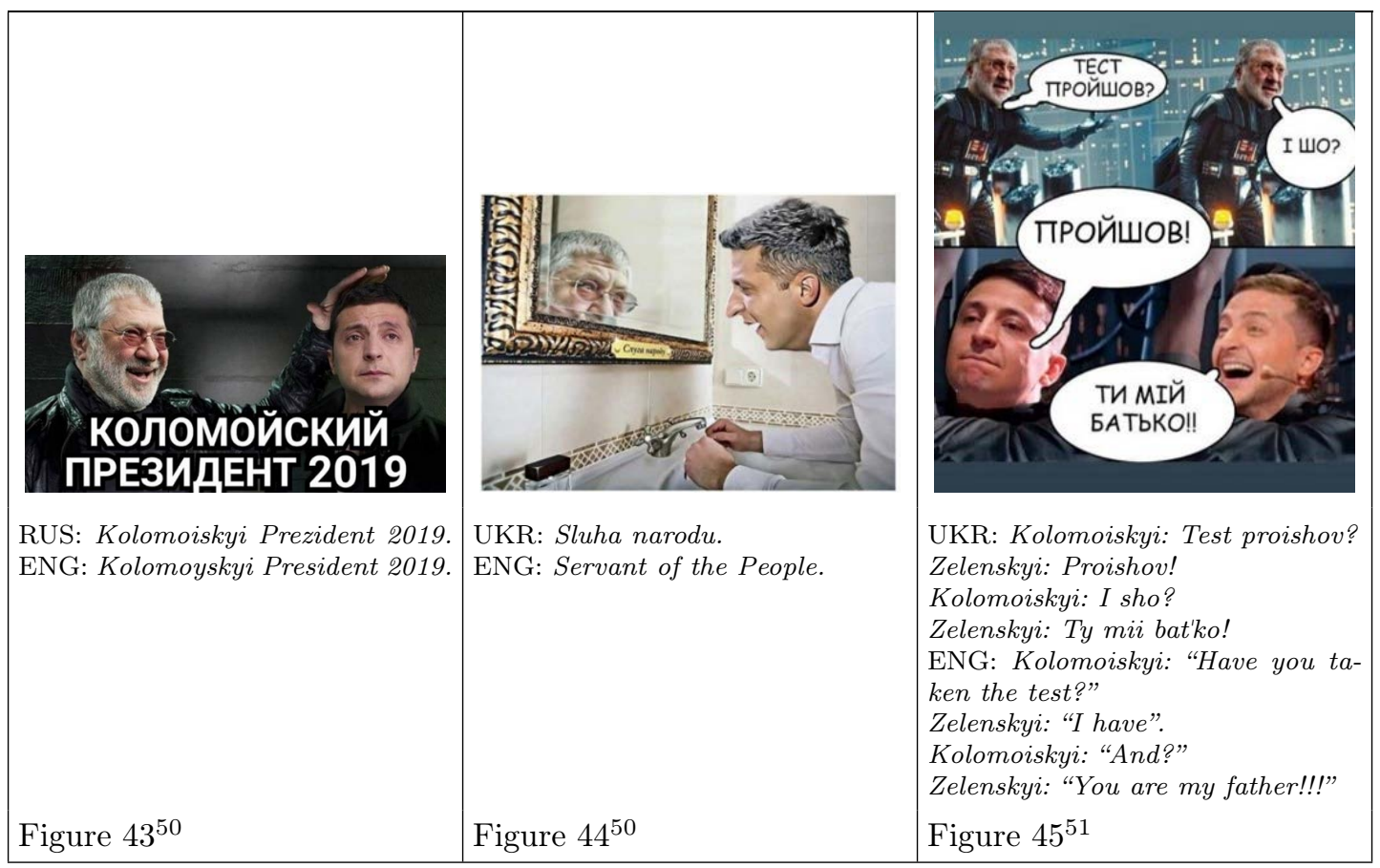

Any picture, phrase, or short saying can become a meme, which is played in various contexts. Volodymyr Zelenskyi starred, at some point in his career as an actor, in a commercial for a jewellery producer, which had as its slogan "Tobi lychyt moie kokhannia" [lit. "You look good in my love"]. Meme creators have used this slogan in creolized texts, having replaced the picture of the sweethearts with a photo of Ihor Kolomoiskyi.

UKR: Tobi lychyt' moie kohannia.
ЕNG: You look good in my love.
Figure ${ }^{52}$ $\begin{aligned} & \begin{array}{l}\text { UKR: Tobi lychyt' moie kohannia. Zolotyi Vik. Iuve- } \\ \text { lirnyi zavod. } \\ \text { ENG: Zolotyi Vik (lit. Golden Age). You look good in } \\ \text { my love. Jewellery producer. Original advertisement. } \\ \text { Figure }\end{array} \\ & \text { 5ign }\end{aligned}$

\footnotetext{
${ }^{50}$ https://vybory.depo.ua/ukr/polya/naysmishnishi-memi-pro-zelenskogo-20190402941463

${ }^{51}$ https://24tv.ua/naysmishnishi_memi_tizhnya_chuvachi_tak_chuvachi_epopeya_z_analizami_i_ litayucha_korova_n1137724

${ }^{52}$ https://enigma.ua/articles/opg-kolomoyskogo-vlada-yaku-vi-zasluzhili-vstup

${ }^{53} \mathrm{http}$ ///aferist.org/evgenij-anisimov-stanet-smotryashhim-za-tenevymi-potokami-ot-zelenskogo/
} 


\section{Conclusion}

As the analysis of political internet memes from Ukraine's 2019 presidential election reveals, the construction of the opponent's image is based on the exaggeration of negative personality traits, stereotypes and rumours. In the Ukrainian context such features as alcoholism, drug addiction, weak intellectual abilities, political past and background, and populist statements were exaggerated. This thematic group of memes is constructed with the use of a great amount of humour, sarcasm, satire and irony. Concerning language, negative connotations and neologisms are widely applied. Moreover, the sources for meme creation include jokes, previous political rhetoric and slogans, and popular songs. The main function of such memes is to depict an opponent in a negative light and to worsen his position in the election race. As a result, these memes created stereotypical images of the candidates.

On the other hand, the thematic group of memes depicting the polarisation of Ukrainian society was created using different sources - mostly medieval pictures and popular memes from Western culture. Several metaphorical scenarios were implied in these meme designs. Firstly, the scenario politics is love was applied - putting the political actors in a sexual context increased attention and affected the feelings of voters. Secondly, the scenario politics is an animal world was used to underline the polarisation, antagonism and unfriendliness of different social groups. Finally, the metaphoric model politics is sport emphasized the tough competition between opponents. Regarding language, the usage of dialect words and popular names assisted in creating a humorous effect.

Numerous memes involved images of other politicians besides the two main candidates in the presidential election. Memes creators thus demonstrated their political connections and influence. Referring to the previous political campaigns or the commercial backgrounds of political actors, this thematic group of memes gives the voters a deeper understanding of socio-political processes. Moreover, these memes are also of a humorous nature; for instance, they often include sexual implications. They create comical images, exploiting the interplay between visual and verbal, between well-known and hidden information.

Thus, during the pre-election campaign in 2019 in Ukraine the internet turned into a battlefield. Candidates were trying to discredit each other using memes, mocking each other's character traits, exaggerating each other's habits, and creating their own positive image against the background of the opponent. Apart from the ironic and mocking tone, political memes often carried an openly offensive message, which was constructed by means of lexemes with negative connotations. It would be revealing to compare political memes created in the Ukrainian segment of the internet with those constructed in other countries during election campaigns. By doing so, the similarities and common mechanisms of political meme construction could be analysed, as could the peculiarities and differences which are based on each country's sociocultural context.

\section{References}

Analizy, debaty i IUlia-sekundant: IAk sotsmerezhi zhartuiut' nad epichnym dvoboiem Poroshenka ta Zelens'koho (foto, video). (2019, April 5). Rakurs. https://racurs.ua/ua/n120375-analizy-debaty-tavybory-vybuhova-reakciya-socmerej-na-batl-poroshenka-ta-zelenskogo-foto-video.html

Arcimavičienè, L. (2011). The complex metaphor of political animals in media political discourse: A crosslinguistic perspective. Studies about Languages, 2011(19), 95-100. https://doi.org/10.5755/j01. sal.0.19.951

Burroughs, B. (2013). Obama trolling: Memes, salutes and agonistic politics in the 2012 presidential election. The Fibreculture Journal, 2013(22), 257-276.

Calimbo, A. (2016). Deconstructing myths via humor: A semiotic analysis of Philippine political internet memes. CASS Langkit Journal, 6, 1-20.

Chen, C. (2012). The creation and meaning of Internet memes in 4chan: Popular Internet culture in the age of online digital reproduction. Habitus, 3, 6-19. 
Chernikova, O. (2015). Verbal'nyı̆ mem: Linhvistychnyı̌ aspekt. Naukovi zapysky Natsional'noho universytetu "Ostroz'ka akademiia". Seriia "Filolohichna", 51, 354-356.

Davison, P. (2012). The language of Internet memes. In M. Mandiberg (Ed.), The social media reader (pp. 120-134). New York University Press.

Deacon, T. W. (1999). Memes as signs. The Semiotic Review of Books, 10(3). http://projects.chass . utoronto.ca/semiotics/srb/10-3edit.html

Dean, J. (2019). Sorted for memes and gifs: Visual media and everyday digital politics. Political Studies Review, 17(3), 255-266. https://doi.org/10.1177/1478929918807483

Denysiuk, Z. (2016). Kreolizovani teksty postfol'kloru iak zasib internet-komunikatsiï. Mizhnarodny Kul'turolohiia. Filolohiia. Muzykoznavstvo, 2016(2), 23-31.

Distracted boyfriend. (n.d.). Know Your Meme. https://knowyourmeme.com/memes/distractedboyfriend

Dziubina, O. (2016). Klasyfikatsiia, struktura ta funktsionuvannia internet-memiv v sotsial'nykh mere-

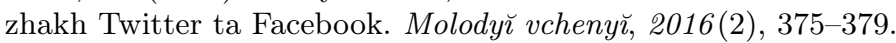

Huntington, H. (2013). Subversive memes: Internet memes as a form of visual rhetoric. Selected Papers of Internet Research, 14.0. https://www.academia.edu/5415739/Subversive_Memes_Internet_Memes_ as_a_Form_of_Visual_Rhetoric?auto=download

Isakova, T. (2016). Mova vorozhnechi iak problema ukraïns'koho informatsiŭnoho prostoru. Stratehichni priorytety, 2016(4), 90-97.

IUzych, I. (2018, October 4). Khto i koly vyhadav haslo "Slava Ukraïni!". Istorychna pravda. https: //www.istpravda.com.ua/articles/2018/10/4/153036/

Ivanchenko, T. (2019, April 8). Analizy, stadion, oktahon - u hri politychni memy. MediaSapiens. https: //ms.detector.media/web/social/analizi_stadion_oktagon_u_gri_politichni_memi/

Karp'iak, O. (2014, August 8). Vata z ukropom: Mova politychnykh memiv. BBC News. https://www. bbc . com/ukrainian/entertainment/2014/08/140807_new_words_ko

Khraban, T. (2018). Prahmatychnyı̌ aspekt funktsionuvannia internet-memiv pid chas rosiǔs'ko-ukraïns' koho konfliktu. Aktual'ni pytannia humanitarnykh nauk, 3(20), 78-83. https://doi.org/10.24919/ $2308-4863.3 / 20 \cdot 167513$

Knobel, M., \& Lankshear, C. (2007). Online memes, affinities, and cultural production. In M. Knobel \& C. Lankshear (Eds.), A new literacies sampler (pp. 199-227). Peter Lang.

Kunstmann, A. (Ed.). (2017). Selfie citizenship. Palgrave Macmillan. https://doi.org/10.1007/978-3$319-45270-8$

Kutsenko, V. (2019). Zelens'kyı - narkoman? Shcho kazhut' likari. UAportal. https://www.uaportal. com/ukr/news/zelenskij-narkoman-scho-kazhut-likari.htm

Kxiva, M., \& Vesik, L. (2009). Contemporary folklore, Internet and communitites at the beginning of the $21^{\text {st }}$ century. In M. Kõiva (Ed.), Media $\&$ Folklore: Contemporary Folklore IV (pp. 97-117). ELM Scholarly Press.

Leiser, A. (2019). Spreadable media, citizens, and participatory culture: use and effects of political Internet memes [PhD dissertation, Bremen International Graduate School of Social Sciences]. Semantic Scholar. https://pdfs.semanticscholar.org/d3aa/71b1e9fc14ec4a49ffbd13d2d86f50b61d55.pdf? _ga $=2.51676329 .124070359 .1581423948-1236568010.1581423948$

Levinson, D. K. (2007). Partizanskaia kreativnost' (I. Tribushnaia, Trans.). Ėksmo.

Lung, J. (2018). Jungle politics: Animal metaphors in international relations. European View, 17(2), 235-237. https://doi.org/10.1177/1781685818809330

Marutian, R. (2017, May 15). Memetychna zbroia iak instrument smyslovoï viüny RF proty Ukraïny. Matrix. https://matrix-info.com/2017/05/15/memetychna-zbroya-yak-instrumentsmyslovoyi-vijny-rf-proty-ukrayiny/

Metahaven. (2013). Can jokes bring down governments? Memes, design, politics. Strelka Press.

Mussolf, A. (2006). Metaphor scenarios in public discourse. Metaphor and Symbol, 21(1), 23-38. https: //doi.org/10.1207/s15327868ms2101_2

My Parents Are Dead / Batman Slapping Robin. (n.d.). Know Your Meme. https://knowyourmeme.com/ memes/my-parents-are-dead-batman-slapping-robin

Neklesova, V. (2016). Memy ukraïns'koho sehmentu Internetu. Zapysky z onomastyky, 19, $151-162$.

Ostanina-Olszewska, J., \& Majdzińska-Koczorowicz, A. (2019). A Cognitive Linguistics approach to internet memes on selected Polish internet sites. Cognitive Studies / Études cognitives, 2019(19), Article 1939. https://doi.org/10.11649/cs.1939 
Piddubny̌̆, A. (2011). Internet-memy v aspekti paradyhmy perekladu. Novosti mirovor nauki (Filologicheskie nauki). http://www.rusnauka.com/13_NMN_2011/Philologia/6_86003.doc.htm

Piñeiro-Otero, T., \& Martínez-Rolán, X. (2016). The use of memes in the discourse of political parties on Twitter: Analysing the 2015 state of nation debate. Communication and Society, 29(1), 145-159. https://doi .org/10.15581/003.29.1.145-159

Pocheptsov, H. (2017, December 24). Memeticheskaia voĭna, ili V poiskakh "arifmetiki" razuma. MediaSapiens. https://ms.detector.media/trends/1411978127/memeticheskaya_voyna_ili_v_poiskakh_ arifmetiki_razuma/

Poroshenko pidpysav zakon, iaky̆ zakripliuie dlia armï $i$ politsï vitannia "Slava Ukraïni! - Heroiam slava!". (2018, October 11). UNIAN. https://www.unian.ua/politics/10295268-poroshenkopidpisav-zakon-yakiy-zakriplyuye-dlya-armiji-i-policiji-vitannya-slava-ukrajinigeroyam-slava.html

Reime, T. (2014). Memes as visual tools for precise message conveying: A potential in the future of online communication development. NTNU. https://www.ntnu.no/documents/10401/1264435841/Design+ Theory+Article+-+Final+Article+-+Thov+Reime.pdf/a5d150f3-4155-43d9-ad3e-b522d92886c2

Seiffert-Brockmann, J., Diehl, T., \& Dobusch, L. (2017). Memes as games: The evolution of a digital discourse online. New Media and Society, 20(8), 2862-2879. https://doi.org/10.1177/ 1461444817735334

Shchurina, I. (2015). Internet-memy: Istochniki vozniknoveniia. Nauchnyて progress na rubezhe tysiacheletiน (Filologicheskie nauki). http://www.rusnauka.com/16_NPRT_2014/Philologia/7_170976.doc.htm

Shomova, S. (2015). Politicheskiǔ internet-mem: Sushchnost', spetsifika, raznovidnosti. Biznes. Obshchestvo. Vlast', 22, 28-41.

Skliarevskaia, H. (2019, April 8). Media pidsylyly emotsiı̆nu skladovu vyboru $\breve{~ v y m k n u l y ~ r a t s i o n a l ' n u: ~}$ Opytuvannia. Detektor Media. https://detector.media/infospace/article/166213/2019-04-08media-pidsilili-emotsiinu-skladovu-viboru-i-vimknuli-ratsionalnu-opituvannya/

Sokolova, K. (2012). Memy iak zasib komunikatsiï v Internet-seredovyshchi. Humanitarny $\breve{~ c h a s o p y s, ~}$ 2012(1), 118-123.

Sreekumar, T., \& Vadrevu, S. (2013). Online political memes and youth political engagement in Singapore. Selected Papers on Internet Research, 14.0. https://www.semanticscholar. org/paper/Online-political-memes-and-Youth-Political-in-Sreekumar-Vadrevu/ 0b756da39b881acd48a1cbcf6bea82dd376113f 4

Stavyts'ka, L. (2005). Ukraïns'kyı̆ zhargon: Slovnyk. Krytyka.

Sushchuk, M. (2019, April 15). IAk zupynyty populizm ta poliaryzatsiiu suspil'stva. Zbruč. https://zbruc. $\mathrm{eu} /$ node $/ 88535$

Thu Hang, N. (2016). Sport metaphors in political news headlines. VNU Journal of Science: Foreign Studies, 32(2), 12-20.

Tryon, C. (2016, August 23). The power of political memes. The Week. https://theweek.com/articles/ 644312/power-political-memes

U Rosï pokazaly mul'tfil'm, iak ukraïns'ka armiia bombyt' Donbas. (2014, August 19). Vashi novyny. https://news.vash.ua/news/rosiyska-propaganda/multfilm/na-tb-rosiyi-pokazaly-multykyak-ukrayinska-armiya-bombyt-donbas

Vieth, D. (2015). The impact of sports metaphors on the media and public sphere. Lexia: Undergraduate Journal in Writing, Rhetoric \& Technical Communication, 3, 2-6.

Zelens'kyı̆ ta Kolomous'ky̆: "Skhemy" vyiavyly try dokazy vplyvu. (2019, April 8). Ukraïna moloda. https: //umoloda.kyiv.ua/number/0/2006/132217/

The article has been prepared in the framework of international cooperation within the LOEWE research cluster "The Regions of Conflicts in Eastern Europe".

The authors declare that they have no competing interests.

The authors' contribution was as follows: Liudmyla Pidkulmukha — Introduction, The Study of Memes in Ukrainian Academic Literature, Constructing the Image of a Political Opponent in Internet Memes, Involving the Other: The Role of Ukrainian Politicians in the Meme War.

Nadiya Kiss - Political Internet Memes - Definitions and State-of-the-Art in Research Methodology, The Polarisation of Ukrainian Society in the Mirror of Memes, Conclusions. 
This is an Open Access article distributed under the terms of the Creative Commons Attribution 3.0 PL License (http://creativecommons.org/licenses/by/3.0/pl/), which permits redistribution, commercial and noncommercial, provided that the article is properly cited.

\section{(C) The Authors 2020}

Publisher: Institute of Slavic Studies, Polish Academy of Sciences

Publishing History: Received 2020-02-18; Accepted 2020-04-14; Published 2020-12-23. 